\title{
The Analyses of Purchasing Decisions and Brand Loyalty for Smartphone Consumers
}

\author{
Yu-Syuan Chen', Tso-Jen Chen², Cheng-Che Lin ${ }^{*}$ \\ ${ }^{1}$ Department of Applied English, Tainan University of Technology, Taiwan \\ ${ }^{2}$ Department of Business Administration, Tainan University of Technology, Taiwan \\ Email: *td0132@mail.tut.edu.tw
}

Received 10 June 2016; accepted 18 July 2016; published 25 July 2016

\begin{abstract}
With the advent of smartphone, customers purchasing smartphones are sharply increasing over years. Since the Smartphone market extend, the major brands are getting more competitive. Each brand manufacturers are dedicating in developing a strong operating system, software applications, fashionable appearance, service quality, and so on. The purpose of this study is to explore consumers' purchasing behavior, determinants of purchasing decision, and factors of brand loyalty of smartphones. The findings stated that some external factors markedly influenced customers on choosing smartphones. For example, a customer bought a smartphone because of the demand for using it. On the contrary, few customers would buy a smartphone due to the pursuit of vogue or modern trend and the influences by other people. Furthermore, some internal elements of decision processes have sharply influence on choosing a smartphone. The majority of respondents agreed that the price, internal functions of a smartphone all played an important role on making a purchasing decision. In the opposite side of our original thinking, ninety-three respondents (37\%) disagreed that they would choose the one with lower price between two smartphones. In the third part related to the brand relationship quality for purchasing a smartphone, most respondents could hurriedly recall the symbolic logo of the brand and the after-sale service would affect their willingness of rebuying the same brand. In contrast, even though the evaluation of this brand is not good, they still intend to continue to buy this brand. Finally, brand loyalty led consumers to happily tell others the advantages of this brand and recommend the purchase, and to rebuy the brand when it launches a new product. In conclusion, Customers' perceived value, brand experience, trust, satisfaction, service quality and commitment are found to be the key influencing factors of brand loyalty.
\end{abstract}

\section{Keywords}

Smartphone, Purchasing Decisions, Brand Relationship Quality, Brand Loyalty

\section{Introduction}

With the rapid development of science and technology, smartphone is a new device with traditional features of a

${ }^{*}$ Corresponding author. 
mobile phone and combines with more advanced computing capability. This new device not only makes and receives phone calls and text messages, but also accesses to the internet and digital media such as picture, music and video. The smartphone become important and inseparable from modern life. According to estimated figures from eMarketer.com on mobile usage worldwide, 2.73 billion people will own and use smartphones monthly by the end of 2018, catapulted more than 55\% comparing to 2014 (Table 1, eMarketer, 2014) [1].

Because the demand of smartphone is increasing day by day, competition in the smartphone market is getting more and more intense. Consumers now have a wide variety to choose. There are more and more factors will affect their buying decision of smartphone. The determining factor to each consumer may different, such as trend, price, brand, operating system, screen size, etc. Nowadays is a customer-oriented era. In the process of purchasing, consumers will not only consider the quality of products, but also concern about the service quality. Therefore, in order to increase consumers' purchasing frequency, company must make consumers feel the special value of the products and services they provide, further raising consumers' satisfaction with this company. To stand out in this competitive market, how to accurately grasp the psychology of consumers is a significant issue for a company.

Each company tries to expand and innovates the much more human-based operating system, more powerful software applications, and more stylish exterior design to attract customers. These years, with the advancement of the technology, the desire of chasing after the mightier smartphone is the main stream in the world. These endless aspirations create the unlimited business of the smartphone. However, the major brands not only went along the multi-function smartphone, but also attempted to investigate the statistics of the market growing to integrate their successful strategy.

\section{Purpose and Significance of the Study}

This study aims to analyze the purchasing decision and brand loyalty of the smartphone consumers in order to give more information for mobile phone manufacturers and related industry. This study will hopefully help the consumers who are facing the dilemma or confused about how to make a decision to choose which brand of smartphone they should buy. This decision may be influenced by many external or internal elements. Moreover, it makes the consumers understand what processes and factors ultimately affect their decisions. This study may be critically important in laying the groundwork for those who want to delve deeper of these issues. Through this study, it provided enough observation to identify problems, analyze various factors, and solutions for consumers and manufacturers. Therefore, the manufacturers should focus on these key factors to develop a strategy for R \& D, marketing, customer service, and other aspects.

\section{Literature Review}

Reviewing past research and reports could provide many ideas and information to trigger this study. The first section defines "What is a smartphone". Since consumer purchasing behavior and consumer decision-making are closely related, second and third sections would focus on consumer behavior and consumer purchase decision models. The fourth and fifth section would show how determinant of purchasing decision and brand relationship quality affect customer's purchasing intention.

Table 1. Smartphone users and penetration worldwide 2012-2018 (eMarketer, 2014) [1].

\begin{tabular}{|c|c|c|c|c|c|c|c|}
\hline & 2012 & 2013 & 2014 & 2015 & 2016 & 2017 & 2018 \\
\hline Smartphone users(billions) & 1.06 & 1.40 & 1.76 & 2.04 & 2.29 & 2.52 & 2.73 \\
\hline —\%change & $58.7 \%$ & $32.3 \%$ & $25.1 \%$ & $16.3 \%$ & $12.2 \%$ & $10.2 \%$ & $8.1 \%$ \\
\hline — $\%$ of mobile users & $25.8 \%$ & $31.9 \%$ & $3708 \%$ & $41.8 \%$ & $45.0 \%$ & $47.7 \%$ & $49.8 \%$ \\
\hline —\% of population & $15.2 \%$ & $19.8 \%$ & $24.5 \%$ & $28.2 \%$ & $31.3 \%$ & $34.2 \%$ & $36.5 \%$ \\
\hline
\end{tabular}

Note: CAGR 2012-2018) = 17.0\%; individuals of any age who own at least one smartphone and use the smartphone(s) at least once per month. Source: eMarketer, June 2014. 


\subsection{Definition of Smartphone}

Chi-Sheng Chen (2007) [2] mentioned that he referred to some literature, and organized a more detailed definition of smartphones. He gave definition from different aspects of appearance, basic functions, data communications, personal data management, PC Synchronization Update, Voice Communications, Processor, Operating System, and Expandability. Yin-Tao Yang (2009) [3] synthesized various scholars' opinions, giving the following definition of smartphone: 1) Based on open operating system platform; 2) Providing Voice (2G, 3G, 3.5G), Internet, PIM, Music, Photography, Electronic Map, other personal mobile commerce, mobile entertainment center and other integrative basic functions; and 3) Providing personalized demand extension by third party software (mobile mall, information centers, etc. Taking all these researches, the definition of smartphones is much more definite.

\subsection{Consumer Purchase Decision Models}

Consumer behavior models are mainly to investigate there will be what kind of impact on consumer behavior under different parameters. Many scholars have proposed a model to explain consumer behavior, and this study will mention two of those. One is Engel-Kollat-Blackwell (EKB) Model (2001) [4] which was proposed jointly by three scholars, Engel, Kollat and Blackwell. The other is Kotler Model (1999) [5] which was proposed by marketing master, Kotler (Kotler, 1999) [5]. Figure 1 details the models; explain their functionality and importance to defining consumers.

\subsection{Determinant of Purchasing Decision}

There are several determinant would affect purchasing decisions of smartphone consumers. For a company, if they can accurately catch on consumer psychology, then they will not have to depend on cutting price to attract consumer. The marketers will know how to set objectives to sell their products in the most appropriate way, especially when the purchaser motives are obviously defined.

Kotler and Armstrong (2013) [6] have stated that product price is the amount of money charged for a product, or the sum of the values that customers exchange for the product. The value of product varies from person to person. There are many methods of pricing: markup pricing, target-return pricing, perceived-value pricing, going rate pricing, and promotional pricing (Kotler and Keller, 2012) [7]. However, how to set up the price which most consumers can accept is very difficult but important.

With the rapid advance of technology, consumers' demands for smartphone functions are getting more. In addition to the existing advantages, the manufacturers must constantly innovate, developing the functions which are useful and ease of use in order to attract consumers (Yeh, 2012) [8]. Therefore, manufacturers should pay attention to the usage of consumers all the time in order to develop the function which meet consumers' needs accurately.

Creusen and Schoormans (2005) [9] have pointed out that the visual appearance of a product could influence consumers' evaluations and choice for products in many ways. The design of a product determines the first impression of the product to consumers, and can deliver product advantage hurriedly. In general, a product with an extraordinary appearance will be preferred (Ricardo, 2008) [10]. Kotler and Armstrong (2013) [6] mentioned that a consumer behavior was influenced by social factors, such as the consumer's small groups, family, and

\section{Kotler Model}

\begin{tabular}{|c|c|c|c|c|c|}
\hline Marketing Stimuli & Other Stimuli & & \multicolumn{2}{|c|}{ Buyer's Black Box } & Buyer's Response \\
\hline $\begin{array}{l}\text { Product } \\
\text { Price } \\
\text { Place } \\
\text { Promotion }\end{array}$ & $\begin{array}{l}\text { Economic } \\
\text { Technological } \\
\text { Political } \\
\text { Cultural }\end{array}$ & $\Rightarrow$ & $\begin{array}{l}\text { Characteristic } \\
\text { Culture } \\
\text { Social } \\
\text { Personal } \\
\text { Psychological }\end{array}$ & $\begin{array}{l}\text { Decision Process } \\
\text { Problem recognition } \\
\text { Information search } \\
\text { Alternatives evaluation } \\
\text { Purchase decision } \\
\text { Post purchase behavior }\end{array}$ & $\begin{array}{l}\text { Products choice } \\
\text { Brand choice } \\
\text { Dealer choice } \\
\text { Purchase timing } \\
\text { Purchase amount }\end{array}$ \\
\hline
\end{tabular}

Figure 1. Kotler model, (Kotler, 1999) [5]. 
social roles and status. According to a research, consumers' purchase behavior is shaped up by others, especially by family members. (Farzana, 2012) [11]. In addition, during the decision making process, consumers can be influenced by close people (family, peers, and colleagues), celebrities, media (promotions and advertisements), people around you, and the Internet (Hayan and Samaan, 2015) [12].

Ali (2012) [13] proposed that brand awareness is the probability that consumers recognize the existence and availability of a company's product. Creating brand awareness by a company is one of the key steps to promote the company's products. A company should step up its publicity to promote the brand awareness, image and identity to be competitive. Further, manufacturers should apply all available communication to develop good flow of information and communication with customers.

Brand relationship quality has three components: trust, commitment and satisfaction (Dorsch et al., 1998; Pi and Huang, 2011) [14] [15]. These three components as a brand relationship quality are very important in the relationship between consumer and brand (Mohammad, Mahmood, and Seyyed, 2011) [16]. They proposed a model called brand relationship quality that describes the relationship among service quality, brand trust, satisfaction, commitment, and exploring the effects of brand experience (repurchase intention). Mohamed and Cherif (2014) described that customer intention to repurchase a brand was influenced by brand relationship quality (brand satisfaction, trust, and commitment), service quality and brand experiences [17].

Repurchase intentions refer to the likelihood of buying a brand again in the future (Boonlertvanich, 2011; Xian, 2012) [18] [19], and it is very important for a brand to increase repurchase intentions of consumers. Repurchase intention was measured with two indicators: repeat purchase intention and repurchase probability (Yi and $\mathrm{La}, 2004$ ) [20]. The research indicated that adjusted expectations can mediate the effect of customer satisfaction on repurchase intention. Particularly, the loyal customer satisfaction had more influence on repurchase intention than low-loyalty customers. Furthermore, the product quality, and brand advertising and name had the highest impact on customers’ purchase intension (Mirabi, Akbariyeh, and Tahmasebifard, 2015) [21].

\section{Methodology}

\subsection{Research Questions}

Customers would take into consideration a lot of factors, such as function, brand, price, and so on when purchasing a smartphone. This study aims to investigate the factors of making purchasing decision by smartphone consumers, and also observe the characteristic influence of a brand on consumers. In accordance with the research purpose, three research questions were posed as follows in order to analyze the process of consumers' purchasing decision.

1) What will prompt consumers' desire to purchase smartphones?

2) What factors will affect the purchasing decision of smartphone consumers?

3) How does brand relationship quality influence customers' purchasing behavior?

\subsection{Instrumentation}

Instrumentation used in this research is questionnaire (Table 2) which has 42 questions and is divided into four sections. First section is Personal Information, and other sections are in the format of a typical five-level Likert Scale. Second section is Consumer Behavior, including internal and external elements, designed to understand what will prompt their desire to purchase a smartphone. Third section is Determinant of Purchasing Decision designed to investigate what factors will affect the purchasing decision of smartphone from consumers. The fourth section is Brand Relationship Quality that is clarified through 13 questions. The second section and third one are assigned to three categories as External elements, External elements, and Brand relationship. According to many scholars' research framework, the study proposes the following framework (Figure 2) and methodology.

\section{Results}

A total amount of two hundred and fifty-two smartphone users' was collected to do the survey questionnaire and run data analysis. The personal data of most respondents is displayed as following: 1) The gender of sex is female (78\%); 2) The age is between 18 - 25 years old (87\%); 3) the educational background is college (95\%); 4) current job is student (73\%); 5) average monthly income is below NT \$30,000 (93\%); and frequency of changing 


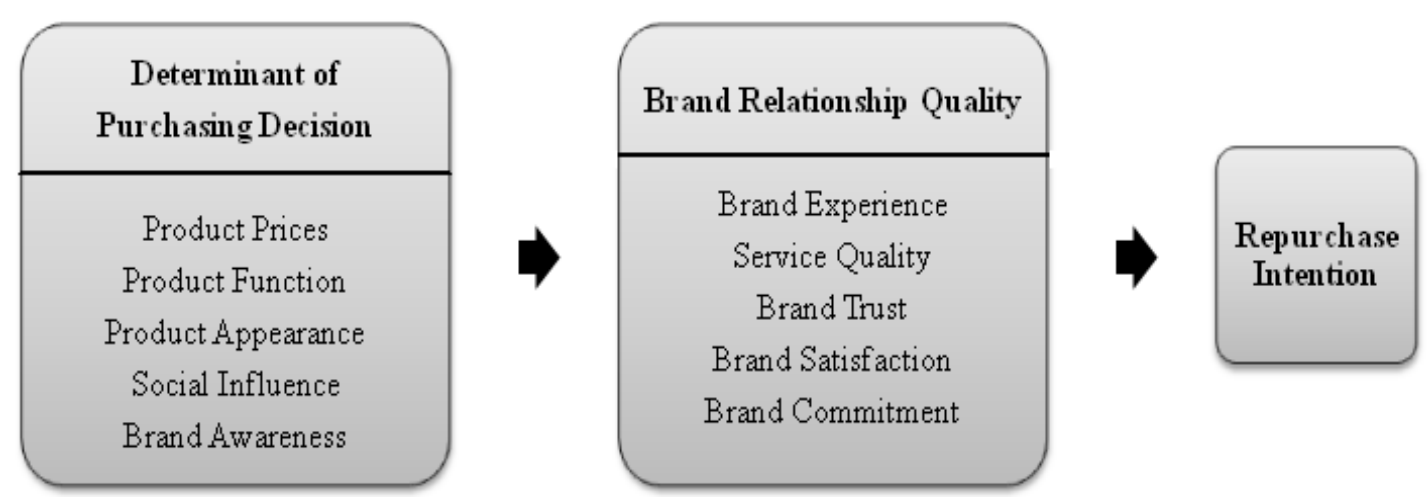

Figure 2. Research framework.

Table 2. Research methodology and questionnaire design.

\begin{tabular}{llc}
\hline \multicolumn{1}{c}{ Research Question } & \multicolumn{1}{c}{ Literature Review } & Questionnaire \\
\hline 1. What will prompt consumers' desire to & 2-1 Consumer Behavior \& Consumer Purchasing Decision & $7-16$ \\
purchase smartphones? & Models (EKB Model; Kotler Model)-External elements & \\
& & $17-18$ \\
& 2-2 Determinant of Purchasing Decision & $19-22$ \\
2. What internal factors will affect the & Product Prices & $23-25$ \\
purchasing decision of smartphone consumers? & Product Function & $26-28$ \\
& Product Appearance & 29 \\
& Social Influence & \\
& Brand Awareness & $30-31$ \\
& & $32-34$ \\
3. How does brand relationship quality & 2-3 Brand Relationship Quality & $35-37$ \\
influence customers' purchasing behavior? & Brand Experience & $38-39$ \\
& Service Quality & 40 \\
& Brand Trust & $41-42$ \\
\hline
\end{tabular}

cellphone is between 1 - 3 years (79\%). From Table 3, the means of the three categories are 3.4, 3.9, and 3.7, that showed internal and brand relationship have more influence. Furthermore, their Cronbach's a are 0.72, 0.71, and 0.83 that means items of the three categories all have good credibility. Form Table 3, Personal income has strongly positive relation with current job of respondents because most respondents are students (73\%) and they have lower income. But personal income had negative relation with frequency of changing smartphone means that many people with higher income would not often change their smartphones. The frequency of changing smartphone has strongly negative relation with external elements and brand relationship, but slightly with internal elements. That means customer would buy this smallphone because of his demand and Internet usage. Moreover, external elements has significantly relation with internal elements, it showed that the purchasing decision making would be influence by product prices, function, appearance, social Influence, and brand awareness. The brand relationship, furthermore, has significantly relation with external and internal elements, it showed that these factors were mutually influenced.

The findings stated that some external factors markedly influenced customers on choosing smartphones. For example, two hundred and thirty-eight respondents $(94 \%$, mean $=4.06)$ strongly agreed or agreed that they bought a smartphone because of the demand for using it. On the contrary, over thirty percent of respondents strongly disagreed or disagreed that they would buy a smartphone due to the pursuit of vogue or modern trend (35\%) and the influences by other people (38\%). The surprising phenomenon is that seventy-five respondents (30\%) strongly disagreed or disagreed that they would like to buy the brand because they had ever seen or heard its attractive advertisements. That brings manufacturers an import clue to effectively control the budget of ad campaigns. 
Table 3. Model analysis.

\begin{tabular}{|c|c|c|c|c|c|c|c|c|c|}
\hline & Sex & Age & Education & $\begin{array}{c}\text { Current } \\
\text { job }\end{array}$ & $\begin{array}{l}\text { Monthly } \\
\text { in come }\end{array}$ & $\begin{array}{l}\text { Frequency } \\
\text { of changing } \\
\text { smartphone }\end{array}$ & $\begin{array}{l}\text { External } \\
\text { elements }\end{array}$ & $\begin{array}{c}\text { Internal } \\
\text { elements }\end{array}$ & $\begin{array}{l}\text { Brand } \\
\text { relationship }\end{array}$ \\
\hline \multicolumn{10}{|l|}{ Sex } \\
\hline Age & $-0.208^{*}$ & & & & & & & & \\
\hline Education & -0.142 & 0.019 & & & & & & & \\
\hline Current job & -0.137 & $0.331^{*}$ & -0.019 & & & & & & \\
\hline Income & $-0.248^{*}$ & $0.472^{*}$ & $0.158^{*}$ & $0.524^{*}$ & & & & & \\
\hline Frequency & -0.037 & $0.136^{*}$ & 0.037 & -0.027 & -0.066 & & & & \\
\hline External & -0.054 & -0.084 & -0.056 & -0.004 & -0.012 & $-0.224^{*}$ & $(0.72)$ & & \\
\hline Internal & 0.008 & -0.058 & 0.046 & -0.009 & -0.052 & -0.080 & $0.478^{*}$ & $(0.71)$ & \\
\hline $\begin{array}{l}\text { Brand } \\
\text { relationship }\end{array}$ & 0.025 & -0.107 & -0.006 & 0.020 & -0.043 & $-0.170^{*}$ & $0.339^{*}$ & $0.419^{*}$ & $(0.83)$ \\
\hline
\end{tabular}

a. $\mathrm{N}=252$, alpha reliabilities are given in parentheses. b. Sex, age, education current job, income, and frequency of changing smartphone are dummycoded. ${ }^{*} p<0.01$.

Furthermore, some internal elements of decision processes have sharply influence on choosing a smartphone. The majority of respondents strongly agreed or agreed that the price $(85 \%$, mean $=4.15)$, Internal functions of a smartphone (including operating system) $(89 \%$, mean $=4.23)$, doing comparison of different brands $(85 \%$, mean = 4.15), a smartphone with user-friendly operation interface $(87 \%$, mean $=4.23)$, battery life $(89 \%$, mean $=$ $4.37)$, and exterior design $(85 \%$, mean $=4.17)$ all played an important role on making a decision to buy. In the opposite side of our original thinking, ninety-three respondents $(37 \%$, mean $=2.99)$ strongly disagreed or disagreed that they would choose the one with lower price between two smartphones.

In the third part related to the brand relationship quality for purchasing smartphone, over eighty percent of respondents strongly agreed or agreed that they could hurried recall the symbolic logo of the brand $(81 \%$, $\mathrm{m}=$ 4.13) and the after-sale service would affect their willingness of rebuying the same brand $(80 \%$, mean $=4.10)$. In contrast, only thirty-five percent of respondents (mean = 3.06) strongly agreed or agreed that Even though the evaluation of this brand is not good, they still intend to continue to buy this brand.

Finally, brand loyalty led consumers to happily tell others the advantages of this brand and recommend the purchase (mean=3.88), and to rebuy the brandwhen it launches a new product (mean=3.67). In conclusion, Customers' perceived value, brand experience, trust, satisfaction, service quality and commitment are found to be the key influencing factors of brand loyalty. In the future, we should extend the survey respondents to different jobs, education level, areas, and so on to get more objective raw data. Comparing to this study, the various groups may indicate many differences or significant meanings that lead the research to high reliability and truthfulness. Therefore, the smartphone manufacturers would like to reference the results of the research to their marketing planning and product design.

\section{Discussion}

For Question 1, “What will prompt consumers’ desire to purchase smartphones?” Based on research results and findings, eighty-six percent of respondents agreed that they buy a smartphone because of demand. Only thirty-six percent of respondents agreed that they buy a smartphone because of the pursuit of popular modern trend, and thirty-six percent of respondents agreed that they buy a smartphone because of the influences by other people. This showed that smartphone already become necessary equipment for modern people. People buy smartphone because of demand, not because of modern trend or the influences by other people.

Among them, sixty percent of respondents agreed that their main purpose of using smartphone is entertainment, and only thirty-six percent of respondents agreed that their main purpose of using smartphone is job demand. Since most of the respondents are students, this resulted in using smartphone for entertainmentas their main purpose. However, a lot of the entertainment features of smartphones need to be connected with the Inter- 
net; thus, there are sixty-nine percent of respondents agreed that the smartphone with mobile internet is necessary.

Except the demand, brand and economy were also the factors that prompt consumers' desire to purchase smartphones. There are forty-four percent of respondents agreed that they would buy the brand because they saw or heard the attractive advertisements, and forty-eight percent of respondents agreed that they would first consider the brand with a high market share. Fifty-five percent of respondents agreed that telecommunication promotions will affect their purchasing decision, and forty-nine percent of respondents agreed that the changes in the domestic economic environment would affect their decision. Therefore, even the percentage are not high, brand and economy were still the factors which need to be concerned about.

For Question 2, "What factors could affect the purchasing decision of smartphone consumers?". According to the sample of research results and findings, first, there are eighty-five percent of respondents agreed that the price will affect their decision when they buy a smartphone. However, only thirty-three percent of respondents agreed that they would choose the one with lower price when they make a choice between two smartphones. This showed that even price is an important factor for smartphone consumers, but it is definitely not the most important factor. Secondly, in terms of product function, most respondents agreed that internal functions (89\%), user-friendly operation interface (87\%), and battery life (89\%) are important to them. In addition to the above, eighty-five percent of respondents agreed that they w compare each brand's difference when they buy a smartphone. Moreover, product appearance is also one of the key factors to attract consumers. Eighty-five percent of respondents agreed that phone's exterior design will affect their decision; seventy-five percent respondents agreed that the screen size of a smartphone is very important, and seventy-five percent of respondents agreed that they would consider the thickness and weight of the smartphone. At last, even if the consumer felt satisfied with the price, function, appearance of a smartphone, they would still be slightly affected by the evaluation of other people or other social influence. Fifty-five percent of respondents agreed that they would be affected by family, friends, or colleagues when choosing a smartphone, sixty-five percent of respondents agreed that they would be affected by advertising or the evaluation from the Internet, and seventy-five percent of respondents agreed that they will collect the information of the smartphone from the Internet or friends. Finally, fifty-seven percent of respondents agreed that they would only consider the brand in their mind.

In summary, each brand launches new smartphones every year, consumers have more choices at the same time. Therefore, consumers will consider more when choosing a smartphone. According to the above mentioned research results and findings, product function will be the factor which consumers most care about, followed by product appearance and product price. However, the consumers' final decision will also slightly affected by social influence and brand characteristics. Consequently, a company should make sure their products always have fine reputation.

For Question 3, “How does brand relationship quality influence customers' purchasing behavior?”. Brand relationship quality includes brand experience, service quality, brand trust, brand satisfaction, brand commitment, and repurchase intention. First, fifty-nine percent of respondents agreed that the smartphone brand which they have being used currently stands ready to provide the latest information to customers, and eighty-two percent of respondents agreed that they could quickly recall the symbolic logo of the brand. If consumers can quickly recall the symbolic logo of a brand, it means that consumers would easy to think of the brand when choosing a new smartphone next time. Thus, providing the latest information to customers is important, because this can strengthen the brand image in consumers' mind, and make them easy to recall the brand anytime. Secondly, service also becomes a kind of product in this era. Nowadays consumers not only care about the physical products, the service quality is also important to them. There are seventy-three percent of respondents agreed that the service staff of the brand can detail the brand's products and meet their needs, seventy percent of respondents agreed that salesperson's service will affected their decision, and seventy-nine percent of respondents agreed that aftersales service will affect their will to buy the brand's smartphone next time.

Thirdly, fifty-two percent of respondents agreed that the smartphone brand which they were using currently is their first choice, fifty-three percent of respondents agreed that they will still choose to buy the brand if the brand is more expensive than other brands, but only thirty-six of percent respondents agreed that they would intend to continue to buy the brand even though the evaluation of the brand is not good. This showed that the consumers with strong trust of any brand were still not accounted for too much proportion, and brand trust is easy to break if there is any bad evaluation of the brand. Fourth, fifty percent of respondents agreed that they will not consider buying other brands when they have a preference for a brand, and seventy-one percent of res- 
pondents agreed that they would love to tell other people about the advantages of the brand which they use their smartphone currently and recommend them to purchase. Consumers are willing to recommend the brand which they are satisfied to other people; however, today's consumers still prefer to compare each brand's difference. In addition to the product itself, consumers attached great importance to the service commitments in the warranty period which the brand provides. The service commitments in the warranty period which the brand provided would affect their buying decision. Finally, fifty-nine percent of respondents agreed that they would consider buying again when the brand which they use their smartphone currently releases a new product, and fifty-five percent of respondents agreed that they would choose the brand which they were using currently again when they want to replace the smartphone. This showed that if a consumer with a strong brand loyalty, they would choose "a brand" instead of "a product".

In the future, we should extend the survey respondents to different jobs, education level, areas, and so on to get more objective raw data. Comparing to this study, the various groups may indicate many differences or significant meaning that lead the research to high reliability and truthfulness. Therefore, the smartphone manufacturers would like to reference the results of the research to their marketing planning and product design.

\section{References}

[1] eMarketer (2014) Worldwide Smartphone Usage to Grow 25\% in 2014. http://www.emarketer.com/Article/Worldwide-Smartphone-Usage-Grow-25-2014/1010920

[2] Chen, C.-S. (2007) The Study of Consumer Behaviors of Smartphone-Based on Business People. http://handle.ncl.edu.tw/11296/ndltd/39118068248653832014

[3] Yang, Y.T. (2009) The Development Trend Analysis of Smart Phone Industry. http://etds.lib.ncku.edu.tw/etdservice/view metadata?etdun=U0026-0812200915390987

[4] Blackwell, R.D., Miniard, P.W. and Engel, J.F. (2001) Consumer Behavior. Dryden Press, Harcourt College Publishers, Ft. Worth, Texas.

[5] Kotler, P. (1999) Marketing Management: Analysis, Planning, Implementation and Control. 9th Edition, Prentice Hall College Inc.

[6] Kotler, P. and Armstrong, G. (2013) Principle of Marketing. 15th Edition, Prentice Hall.

[7] Kotler, P. and Keller, K.L. (2012) Marketing Management. 14th Edition, Pearson Education.

[8] Yeh, Y.F. (2012) Smartphone Usage in Taiwan. http://yehyi.wordpress.com/2012/04/13/week-11-smartphone-usage-in-taiwan-with-charts/

[9] Creusen, M.E.H. and Schoormans, J.P.L. (2005) The Different Roles of Product Appearance in Consumer Choice. The Journal of Product Innovations Management, 22, 63-81. http://dx.doi.org/10.1111/j.0737-6782.2005.00103.x

[10] Ricardo, P.G. (2008) Consumer Behavior: Product Characteristics and Quality Perception. http://mpra.ub.uni-muenchen.de/11142/

[11] Farzana, W. (2012) Consumers’ Psychological Factors Association with Brand Equity of High Involvement Product: Case of Laptop. World Journal of Social Sciences, 2, 90-101.

[12] Hayan, D. and Samaan, A.M. (2015) The Effects of the Determinants of Customer Satisfaction on Brand Loyalty. Journal of Research in Business and Management, 3, 1-12.

[13] Ali, H. (2012) Customer's Satisfaction and Brand Awareness. https://www.theseus.fi/bitstream/handle/10024/52815/Ali_Hussein.pdf?sequence=1

[14] Dorsch, M.J., Swanson, S.R. and Kelley, S.W. (1998) The Role of Relationship Quality in the Stratification of Vendors as Perceived by Customers. Academy of Marketing Science, 26, 128-142. http://dx.doi.org/10.1177/0092070398262004

[15] Pi, W.P. and Huang, H.H. (2011) Effects of Promotion on Relationship Quality and Customer Loyalty in the Airline Industry. African Journal of Business Management, 5, 4403-4414.

[16] Mohammad, T., Mahmood, S.L. and Seyyed, J.M. (2011) The Investigation and Analysis Impact of Brand Dimensions on Services Quality and Customers Satisfaction in New Enterprises of Iran. Contemporary Marketing Review, 1, 1-13. http://www.businessjournalz.org/articlepdf/cmr_1601.pdf

[17] Mohamed, N.B. and Cherif, G. (2014) Loyalty and Innovation: Evidence from Algerian Mobile Service Providers. International Journal of Technology Management \& Sustainable Development, 13, 73-96. http://dx.doi.org/10.1386/tmsd.13.1.73_1

[18] Boonlertvanich, K. (2011) A Conceptual Model for the Repurchase Intentions in the Automobile Service Industry: The Role of Switching Barriers in Satisfaction-Repurchase Intentions Relationship. International Journal of Business Re- 
search, 9, 1-18.

[19] Xian, W. (2012) Brand Image, Service Quality, Satisfaction and Loyalty Affect Willingness to Buy the Smartphone. M.D. Thesis, Department of Information Management National Formosa University, Taiwan.

[20] Yi, Y. and La, S. (2004) What Influences the Relationship between Customer Satisfaction and Repurchase Intention? Investigating the Effects of Adjusted Expectations and Customer Loyalty. Psychology and Marketing, 21, 351-373. http://dx.doi.org/10.1002/mar.20009

[21] Mirabi, V., Akbariyeh, H. and Tahmasebifard, H. (2105) A Study of Factors Affecting on Customers Purchase Intention. Journal of Multidisciplinary Engineering Science and Technology, 2, 267-273.

Submit or recommend next manuscript to SCIRP and we will provide best service for you:

Accepting pre-submission inquiries through Email, Facebook, Linkedin, Twitter, etc A wide selection of journals (inclusive of 9 subjects, more than 200 journals)

Providing a 24-hour high-quality service

User-friendly online submission system

Fair and swift peer-review system

Efficient typesetting and proofreading procedure

Display of the result of downloads and visits, as well as the number of cited articles

Maximum dissemination of your research work

Submit your manuscript at: http://papersubmission.scirp.org/ 